\title{
Correlation of duration, hypertension and glycemic control with microvascular complications of diabetes mellitus at a tertiary care hospital
}

\author{
Ramnath Santosh Ramanathan, MD* \\ Akron Neurology Inc, Akron, Ohio, USA
}

\begin{abstract}
Aim: To evaluate microvascular complications in Diabetes Mellitus (DM) and to study correlation of Microvascular Complication with duration of diabetes, glycemic control and hypertension in a tertiary care centre. Though the study is not uncommon there are very few published reports on correlation of all three factors (together in the same study) with microvascular complications of diabetes mellitus.

Materials and methods: Design: Retrospective, observational study. The study has been done through 2007 to 2009 in general hospital, Ahmedabad, India and comprises of 500 patients with Diabetes Mellitus with detailed history, physical examination and laboratory investigations including vibration perception test/ electromyography/nerve conduction velocity, fundus examination and urine for microalbuminuria/urine for protein.

Results: Diabetic Retinopathy was the most common complication observed in the present study with prevalence of $42 \%$ (210/500) followed by Diabetic Neuropathy with a prevalence of 38\% (190/500) and Diabetic Nephropathy with a prevalence of 35\% (175/500). Diabetic Retinopathy, Neuropathy and Nephropathy all were associated with poor glycemic control. 190/210 (90\%) patients of Diabetic Retinopathy, 175/190 (92\%) patients of Diabetic Neuropathy and all 175 patients of Diabetic Nephropathy had associated hypertension. 85/210 (40\%) patients of Diabetic Retinopathy had duration between 10-15 years, 115/210 (55\%) patients of Diabetic Retinopathy had a duration of >15 years, 70/190 (37\%) patients of Diabetic Neuropathy had duration of DM 10-15 years and 70/190 (37\%) patients had duration of DM >15years. 95/175 (54\%) patients of Diabetic Nephropathy had a duration of DM $>15$ years. $70 \%$ diabetic patients with no microvascular complications had duration of diabetes $<5$ years while $83 \%$ diabetic patients with no microvascular complications had HbA1c $<7.0 \%$.

Conclusion: In our experience, long duration of Diabetes, poor glycemic control and associated hypertension all increased the chances of microvascular complications of diabetes.
\end{abstract}

\section{Introduction}

Diabetes Mellitus (DM) is a chronic disorder characterized by impaired metabolism of glucose and other energy yielding fuels as well as by the late development of vascular and neuropathic complications. Diabetes comprises of a group of disorders involving distinct pathogenic mechanisms, for which hyperglycemia is a common denominator. Both types of diabetes are preceded by a phase of abnormal glucose hemostasis as the pathogenic processes progress. Type I diabetes is the result of complete or near total insulin deficiency. Type II DM is a heterogeneous group of disorder characterized by variable degree of insulin resistance, impaired insulin secretion and increased glucose production. Diabetes is etiologically classified as Type I, Type II, other specific types as genetic defects, disease of exocrine pancreas, endocrinopathies, drug induced, infections, uncommon forms of immune-mediated diabetes and gestational diabetes.

Type I DM is the result of interactions of genetic environment and immunological factors that ultimately lead to the destruction of the pancreatic beta cells and insulin deficiency. Type II DM is characterized by insulin resistance, impaired insulin secretion and increased hepatic glucose production. Complication of diabetes are acute like diabetic ketoacidosis and hyperglycemic hyperosmolar state and chronic like microvascular complications-retinopathy, neuropathy and nephropathy and macrovascular complications. Diabetic Retinopathy may be the most common microvascular complication of diabetes and is responsible for 10,000 new cases of blindness every year in United States alone $[1,2]$.

\section{Materials and methods}

This is a retrospective observational study done through 2007 to 2009 in a tertiary care general hospital and comprises a study group of 500 patients who were subjected to detailed history, physical investigations and laboratory investigations.

The diagnosis and classification of diabetes as Type I and Type II is based on ADA guidelines 2007. The patients' history, laboratory investigations and physical examination was obtained by retrospective chart review and medical record review.

All 500 patients apart from being subjected to detailed history and

Correspondence to: Ramnath Santosh Ramanathan, MD, Akron Neurology Inc, Akron, Ohio, USA, E-mail: dr.santosh7@gmail.com

Key words: microvascular complications, diabetes mellitus, nephropathy, neuropathy, retinopathy

Received: January 24, 2017; Accepted: February 17, 2017; Published: February 21,2017 
physical examination had undergone detailed laboratory investigations in form of random blood sugar, fasting and postprandial blood sugar, $\mathrm{HbAlc}$, s. creatinine, urine for protein and microalbuminuria, ultrasound for kidney size, fundus examination, vibration perception test, electromyography and nerve conduction velocity tests.

\section{Results}

In our study, Male to Female ratio was 1.08:1. Maximum incidence of diabetes was seen between $60-79$ years in $240(48 \%)$ patients. Mean age of the group was 55.02 years (Table 1). 420 (84\%) patients in the study had type II DM (Table 2). 160 (32\%) patients had DM for 1115 years (Table 3 ). In our study, microvascular complications were present in $385(77 \%)$ patients (Table 4 ).

95 (83\%) patients of the 115 patients without microvascular complications of had HbAlc < 7.0 (Table 5). 80 (70\%) patients of the115 patients without microvascular complications had duration $<$ 5 years (Table 6 ).

210 (42\%) patients had Diabetic retinopathy and 140 (66.66\%) patients of those had non-proliferative diabetic retinopathy (NPDR) while the remaining $70(33.3 \%)$ patients had proliferative diabetic retinopathy (PDR) and all patients with PDR had duration of diabetes $>15$ years (Tables 7 and 8 ). 175 (35\%) patients had diabetic nephropathy while 190 (38\%) patients had diabetic neuropathy (Tables 9 and 10). Most Common risk factor in personal history was tobacco/smoking seen in $210(42 \%)$ patients (Table 11$)$.

According to American Diabetic Association (ADA) the cut off point for hypertension in diabetic patient is $130 / 80 \mathrm{mmHg}$ and in this study hypertension was present in 385 (77\%) patients (Table 12).

80/115 (70\%) diabetic patients with no microvascular complications

Table 1. Age and Sex Incidence in 500 Diabetic Patients.

\begin{tabular}{|l|l|l|l|l|}
\hline Age in years & Male & Female & Total & Percentage \\
\hline $20-39$ & 35 & 55 & 90 & 18 \\
\hline $40-59$ & 100 & 70 & 170 & 34 \\
\hline $60-79$ & 125 & 115 & 240 & 48 \\
\hline Total & 260 & 240 & 500 & 100 \\
\hline
\end{tabular}

Table 2. Type of Diabetes Mellitus (DM).

\begin{tabular}{|l|l|l|}
\hline Type of DM & No. of patients & Percentage \\
\hline Type I & 80 & 16 \\
\hline Type II & 420 & 84 \\
\hline Total & 500 & 100 \\
\hline
\end{tabular}

Table 3. Summarizes the duration of Diabetes in years.

\begin{tabular}{|l|l|l|}
\hline Duration in years & No. of patients & Percentage \\
\hline$<1$ & 10 & 2 \\
\hline $1-5$ & 95 & 19 \\
\hline $6-10$ & 125 & 25 \\
\hline $11-15$ & 160 & 32 \\
\hline $16-20$ & 90 & 18 \\
\hline$>20$ & 20 & 4 \\
\hline Total & 500 & 100 \\
\hline
\end{tabular}

Table 4. Characterizes the microvascular complications in Diabetes.

\begin{tabular}{|l|l|l|}
\hline $\begin{array}{l}\text { Microvascular } \\
\text { Complications }\end{array}$ & Total Patients & Percentage \\
\hline Present & 385 & 77 \\
\hline Absent & 115 & 23 \\
\hline Total & 500 & 100 \\
\hline
\end{tabular}

Table 5. Differentiates patients based on HbAlc (hemoglobin A1c). Patients without microvascular complications.

\begin{tabular}{|l|l|l|}
\hline HbA1c & Patients & Percentage \\
\hline$<7.0 \%$ & 95 & 83 \\
\hline$>7.0 \%$ & 20 & 17 \\
\hline Total & 115 & 100 \\
\hline
\end{tabular}

Table 6. Summarizes the duration of diabetes in the study patient population. Patients without microvascular complications.

\begin{tabular}{|l|l|l|}
\hline Duration of Diabetes & No. of Patients & Percentage \\
\hline < 5 years & 80 & 70 \\
\hline > 5 years & 35 & 30 \\
\hline Total & 115 & 100 \\
\hline
\end{tabular}

Table 7. Summarizes Diabetic Retinopathy as a microvascular complication in Diabetic patients.

\begin{tabular}{|l|l|l|}
\hline Diabetic Retinopathy & No. of Patients & Percentage \\
\hline Present & 210 & 42 \\
\hline Absent & 290 & 58 \\
\hline Total & 500 & 100 \\
\hline
\end{tabular}

Table 8. Characterizes the severity of Diabetic Retinopathy.

\begin{tabular}{|l|l|l|}
\hline Diabetic Retinopathy & No. of patients & Percentage \\
\hline NPDR & 140 & 66.66 \\
\hline PDR & 70 & 33.33 \\
\hline Total & 210 & 100 \\
\hline
\end{tabular}

Table 9. Summarizes Diabetic Nephropathy as a microvascular complication of Diabetes.

\begin{tabular}{|l|l|l|}
\hline Diabetic Nephropathy & No. of Patients & Percentage \\
\hline Present & 175 & 35 \\
\hline Absent & 325 & 65 \\
\hline Total & 500 & 100 \\
\hline
\end{tabular}

Table 10. Diabetic Neuropathy as a microvascular complication of diabetes.

\begin{tabular}{|l|l|l|}
\hline Diabetic Neuropathy & No. of Patients & Percentage \\
\hline Present & 190 & 38 \\
\hline Absent & 310 & 62 \\
\hline Total & 500 & 100 \\
\hline
\end{tabular}

Table 11. Summarizes social history and risk factors in the study population with diabetes.

\begin{tabular}{|l|l|l|}
\hline Personal History & No. of patients & Percentage \\
\hline Alcohol & 70 & 14 \\
\hline Obesity & 160 & 32 \\
\hline Tobacco/Smoking & 210 & 42 \\
\hline
\end{tabular}

Table 12. Summarizes the association of microvascular complications with Hypertension.

\begin{tabular}{|l|l|l|}
\hline Blood Pressure & No. of Patients & Percentage \\
\hline$<130 / 80 \mathrm{mmHg}$ & 115 & 23 \\
\hline$>130 / 80 \mathrm{mmHg}$ & 385 & 77 \\
\hline Tobacco/Smoking & 210 & 42 \\
\hline
\end{tabular}

had duration of diabetes $<5$ years while $95 / 115$ (83\%) patients with no microvascular complications had $\mathrm{HbAlc}<7.0 \%$.

In our present study $85 / 210$ (40\%) patients with diabetic retinopathy had duration of diabetes $10-15$ years while $115 / 210$ (55\%) had duration $>15$ years (Table 13). All 210 patients with diabetic retinopathy had HbA1c $>7.0 \%$ which implies poor glycemic control while $190 / 210$ (90\%) patients with diabetic retinopathy had hypertension. (Tables 14 and 15).

Diabetic Neuropathy was seen in 20/190 (10.5\%) patients with duration of diabetes $>20$ years while when duration of diabetes was 
$<5$ years the prevalence of diabetic neuropathy was the least. 185/190 (97\%) with diabetic neuropathy had HbA1c $>7.0 \%$ which again implies poor glycemic control and $175(92 \%)$ patients with diabetic neuropathy had hypertension (Tables 13-15).

95/175 (54\%) patients with diabetic nephropathy had duration of diabetes $>15$ years. All diabetic nephropathy patients had HbAlc $>7.0 \%$ which implies poor glycemic control and all patients with diabetic nephropathy had hypertension (Tables 13-15).

\section{Discussion}

Our study shows a clear correlation of longer duration, poor glycemic control and hypertension with microvascular complications of diabetes. Microvascular complications affect millions of patients with Type II DM. These microvascular complications could lead to visual, renal as well as neurological function impairment including death and also increase the cost to the patient and society.

Development of diabetic retinopathy was found to be related to duration, severity of hyperglycemia and presence of hypertension in the UKPDS and most patients with type I DM develop evidence of retinopathy within 20 years of diagnosis [2-4]. The level of glycaemia seems to be the strongest factor influencing the onset of microalbuminuria [5-9]. In UKPDS, the incidence of microalbuminuria was $2 \%$ /year in patients with type II DM and the 10 year prevalence after diagnosis was $25 \%[10,11]$. Diabetic Neuropathy occurs in $50 \%$ of individuals with long standing type I and type II DM. The most rapid deterioration of nerve function occurs soon after type I DM onset. But within 2 to 3 years the progression slows [12].

In our study $85 / 210(40 \%)$ patients with diabetic retinopathy had duration of diabetes 10-15 years while 115/210 (55\%) had duration $>15$ years. All 210 patients with diabetic retinopathy had $\mathrm{HbAlc}>7.0 \%$ which implies poor glycemic control while 190/210 (90\%) patients with

Table 13. Characterizes correlation of duration of DM with microvascular complications.

\begin{tabular}{|l|l|l|l|l|}
\hline $\begin{array}{l}\text { Duration in } \\
\text { years }\end{array}$ & $\begin{array}{l}\text { No } \\
\text { complications }\end{array}$ & $\begin{array}{l}\text { Diabetic } \\
\text { Retinopathy }\end{array}$ & $\begin{array}{l}\text { Diabetic } \\
\text { Neuropathy }\end{array}$ & $\begin{array}{l}\text { Diabetic } \\
\text { Nephropathy }\end{array}$ \\
\hline$<1$ & 10 & - & - & - \\
\hline $1-5$ & 70 & - & - & 25 \\
\hline $6-10$ & 35 & 10 & 50 & 35 \\
\hline $10-15$ & - & 85 & 70 & 20 \\
\hline $16-20$ & - & 95 & 50 & 75 \\
\hline$>20$ & - & 20 & 20 & 20 \\
\hline Total & 115 & 210 & 190 & 175 \\
\hline
\end{tabular}

Table 14. Correlation of glycemic control with Microvascular Complications.

\begin{tabular}{|l|l|l|l|l|}
\hline HbA1c & $\begin{array}{l}\text { No } \\
\text { Microvascular } \\
\text { complications }\end{array}$ & $\begin{array}{l}\text { Diabetic } \\
\text { Retinopathy }\end{array}$ & $\begin{array}{l}\text { Diabetic } \\
\text { Neuropathy }\end{array}$ & $\begin{array}{l}\text { Diabetic } \\
\text { Nephropathy }\end{array}$ \\
\hline$<7.0$ & 95 & 00 & 5 & 00 \\
\hline $7.1-8.0$ & 20 & 60 & 85 & 70 \\
\hline $8.1-9.0$ & 00 & 85 & 60 & 60 \\
\hline$>9.1$ & 00 & 65 & 40 & 45 \\
\hline Total & 115 & 210 & 190 & 175 \\
\hline
\end{tabular}

Table 15. Correlation of Hypertension with Microvascular complications of DM.

\begin{tabular}{|l|l|l|l|l|}
\hline Blood Pressure & $\begin{array}{l}\text { No } \\
\text { Microvascular } \\
\text { Complications }\end{array}$ & $\begin{array}{l}\text { Diabetic } \\
\text { Retinopathy }\end{array}$ & $\begin{array}{l}\text { Diabetic } \\
\text { Neuropathy }\end{array}$ & $\begin{array}{l}\text { Diabetic } \\
\text { Nephropathy }\end{array}$ \\
\hline$<130 / 80 \mathrm{mmHg}$ & 80 & 20 & 15 & 00 \\
\hline$>130 / 80 \mathrm{mmHg}$ & 35 & 190 & 175 & 175 \\
\hline Total & 115 & 210 & 190 & 175 \\
\hline
\end{tabular}

diabetic retinopathy had hypertension. Diabetic Neuropathy was seen in $20 / 190(10.5 \%)$ patients with duration of diabetes $>20$ years while when duration of diabetes was $<5$ years the prevalence of diabetic neuropathy was the least. 185/190 (97\%) with diabetic neuropathy had HbAlc $>7.0 \%$ which again implies poor glycemic control and $175(92 \%)$ patients with diabetic neuropathy had hypertension. 95/175 (54\%) patients with diabetic nephropathy had duration of diabetes $>15$ years. All diabetic nephropathy patients had HbAlc $>7.0 \%$ which implies poor glycemic control and all patients with diabetic nephropathy had hypertension.

The most important pathogenesis leading to microvascular damage is that hyperglycemia damages capillary endothelial cells in the retina, mesangial cells in the renal glomeruli and Schwan cells of the peripheral [13]. Due to hyperglycemia, there is excess glucose transport in these endothelial cells which leads to damage of these cells. Thus, microvascular complications arises as a result of damage inside these endothelial cells $[13,14]$.

Current evidence does support direct relationship between hypertension and poor glycemic control with microvascular complications as also seen in our study. These are termed as independent risk factors for microvascular disease progression [15]. Age, glycated hemoglobin, duration of diabetes, and serum triglycerides are other risk factors as well as smoking, obesity, physical inactivity [16].

The most common cause of blindness in patient with diabetes is diabetic retinopathy. It is estimated to affect up to 3 million people in the United States alone, by 2050 [17]. The main screening method is annual dilated eye examination to detect diabetic retinopathy $[18,19]$. Hyperglycaemia and hypertension are the main risk factors of developing retinopathy in patients with diabetes as also seen with our study [20]. Vascular Diabetic Complications in Southeast Sweden (VISS) study reported similar findings [21]. The VISS study a longitudinal observational study of 451 patients with diabetes who were followed for up to 24 years found that keeping HBA1c below $7.6 \%$ was beneficial in preventing retinopathy and persistent microalbuminuria for up to 20 years [21]. Intensive blood pressure control in patients with type 2 diabetes reduced the incidence and progression of diabetic neuropathy over 4-5 years follow up similar to the results in our study.

Diabetic neuropathy most commonly manifests as distal, symmetrical sensorimotor neuropathy [22]. Patient can have negative symptoms in the form of numbness or positive symptoms like tingling, and/or burning pain. It is mainly diagnosed clinically. The tests that can be used include vibration studies and ultrasound. Management should be prompt as delay can have deleterious effects resulting in gangrene and amputations [23,24]. Management includes good glycemic control as well pharmacological management with tricyclic antidepressants, gabapentin, SSRI (selective serotonin reuptake inhibitors), opioids, antiepileptics, and benzodiazepines [24-27]. Patients can also be offered certain nonpharmacological management in form of nerve stimulation, electromagnetic field treatment as well as should be advised improvements in sleep quality, and stress reduction [25].

It is known that diabetic nephropathy occurs in up to $40 \%$ of all of patients with diabetes, almost similar to our study in which $35 \%$ patients had diabetic nephropathy [28]. Poor glycemic control and hypertension damage the glomeruli. Tight glycemic control is very prudent in primary prevention of micro-albuminuria as seen in various studies $[20,29]$. Angiotensin receptor blocker or angiotensin converting enzyme inhibitor is used in the management of diabetic 
nephropathy along with tight glycemic control, hypertension control, as well as reduced salt intake.

The limitation of our study is that it is retrospective observational study but it does validate the findings of those few studies that are available in the literature, which have shown poor glycemic control and hypertension to be associated with microvascular complications of diabetes.

\section{Conclusion}

Microvascular complications tend to occur in those diabetic patients who have long duration of the disease, hypertension and poor glycemic control.

\section{References}

1. Fong DS, Aiello LP, Ferris FL, Klein R (2004) Diabetic retinopathy. Diabetes Care 27: 2540-2553. [Crossref]

2. Fowler MJ (2008) Microvascular and Macrovascular Complications of Diabetes. Clinical Diabetes-Diabetes Foundation 26: 77-79

3. UK Prospective Diabetes Study group (1998) Intensive blood glucose control with sulphonylureas or insulin compared with conventional treatment and risk of complications in patients with type II DM (UKPDS 33) Lancet 352: 837-853.

4. Keenan HA, CostaCou T, Sun JK (2007) Clinical factors associated with resistance to microvascular complications in diabetes patients of extreme disease duration: the 50th year medalist study. Diabetes Call 30: 95-97.

5. Krolewski AS, Laffel LM, Krolewski M, Quinn M, Warram JH (1995) Glycosylated hemoglobin and the risk of microalbuminuria in patients with insulin-dependent diabetes mellitus. $N$ Engl $J$ Med 332: 1251-1255. [Crossref]

6. Mathiesen ER, Rønn B, Storm B, Foght H, Deckert T (1995) The natural course of microalbuminuria in insulin-dependent diabetes: a 10-year prospective study. Diabet Med 12: 482-487. [Crossref]

7. Coonrod BA, Ellis D, Becker DJ, Bunker CH, Kelsey SF, et al. (1993) Predictors of microalbuminuria in individuals with IDDM. Pittsburgh Epidemiology of Diabetes Complications Study. Diabetes Care 16: 1376-1383. [Crossref]

8. Risk factors for development of microalbuminuria in insulin dependent diabetes mellitus patients, a cohort study. Microalbuminuria collaborative study group, U.K. BMJ 306: 1235-1239.

9. Scott LJ, Warram JH, Hanna LS (2001) A non-linear effect of hyperglycemia and current cigarette smoking are major determinants of the onset of microalbuminuria in type I DM. Diabetes 50: 2842-2849.

10. Gross JL, de Azevedo MJ, Silveiro SP, Canani LH, Caramori ML, et al. (2005) Diabetic nephropathy: diagnosis, prevention, and treatment. Diabetes Care 28: 164 176. [Crossref]

11. Adler AI, Stevens RJ, Manley SE, Bilous RW, Cull CA, et al. (2003) Development and progression of nephropathy in type 2 diabetes: the United Kingdom Prospective Diabetes Study (UKPDS 64). Kidney Int 63: 225-232. [Crossref]

12. Vinik AI, Mehrabyan A (2004) Diabetic neuropathies. Med Clin North Am 88: 947-999. [Crossref]
13. Li TC, Kardia SL, Li CI (2015) Glycemic control paradox: poor glycemic control associated with higher one-year and eight-year risks of all-cause hospitalization but lower one-year risk of hypoglycemia in patients with type 2 diabetes. Metabolism 64 : 1013-1021

14. Zoungas S, Chalmers J, Ninomiya T (2012) Association of HbAlc levels with vascular complications and death in patients with type 2 diabetes: evidence of glycaemic thresholds. Diabetologia 55: 636-643.

15. He Z, King GL (2004) Microvascular complications of diabetes. Endocrinol Metab Clin North Am 33: 215-238. [Crossref].

16. Lin EH, Rutter CM, Katon W, Heckbert SR, Ciechanowski P, et al. (2010) Depression and advanced complications of diabetes: a prospective cohort study. Diabetes Care 33: 264-269. [Crossref]

17. Saaddine JB, Honeycutt AA, Narayan V (2008) Projection of diabetic retinopathy and other major eye diseases among people with diabetes mellitus: United States, 20052050. Arch Ophthalmol 126: 1740-7.

18. Franklin SW, Rajan SE (2014) Diagnosis of diabetic retinopathy by employing image processing technique to detect exudates in retinal images. IET Image Process 8: 601619.

19. Zhang X, Wang N, Schachat AP (2014) Glucocorticoids: structure, signaling and molecular mechanisms in the treatment of diabetic retinopathy and diabetic macular edema. Current Mol Med 14:376-84.

20. UK Prospective Diabetes Study Group (1998) Tight blood pressure control and risk of macrovascular and microvascular complications in type 2 diabetes: UKPDS 38. BMJ 31:7160-703.

21. Nordwall M, Abrahamsson M, Dhir M (2015) Impact of HbAlc, followed from onse of type 1 diabetes, on the development of severe retinopathy and nephropathy: the VISS Study (Vascular Diabetic Complications in Southeast Sweden). Diabetes Care 38: 308-315.

22. Zochodne DW, Malik RA (2014) Mechanisms of diabetic neuropathy: schwann cells In: Aminoff, Boller, Swaab, editors. Diabetes and the Nervous System: Handbook of Clinical Neurology 2014126: 401

23. Tesfaye S, Chaturvedi N, Eaton SE, Ward JD, Manes C, et al. (2005) Vascular risk factors and diabetic neuropathy. $N$ Engl J Med 352: 341-350. [Crossref].

24. Callaghan Brian C, Cheng Hsinlin T, Stables Catherine L (2012) Diabetic neuropathy: clinical manifestations and current treatments. Lancet Neurol 6: 521-534.

25. Franco LC, Souza LA, Pessoa AP (2011) Nonpharmacologic therapies in diabetic neuropathic pain: a review. Acta Paulista de Enfermagem 24: 284-288.

26. Khalil H (2013) Painful diabetic neuropathy management. Int J Evid Based Healthc 11: 77-79. [Crossref].

27. Cohen K, Shinkazh N, Frank J, Israel I, Fellner C (2015) Pharmacological treatment of diabetic peripheral neuropathy. $P$ T 40: 372-388. [Crossref].

28. Stavniichuk, Shevalye H, Lupachyk S (2014) Peroxynitrite and protein nitration in the pathogenesis of diabetic peripheral neuropathy. Diabetes Metab Res Rev 30: 669-678.

29. DCCT Research Group (1988) Factors in development of diabetic neuropathy: baseline analysis of neuropathy in feasibility phase of Diabetes Control and Complications Trial (DCCT). Diabetes 37: 476-481.

Copyright: (C2017 Ramanathan RS. This is an open-access article distributed under the terms of the Creative Commons Attribution License, which permits unrestricted use, distribution, and reproduction in any medium, provided the original author and source are credited. 